\title{
Analýza ustálených slovných spojení so sub- stantívami lockdown a shutdown v slovenčine a mad'arčine
}

\author{
Edina Borovská - Simona Tomášková
}

\begin{abstract}
Analysis of Collocations with the Nouns lockdown and shutdown in Slovak and Hungarian

Abstract

The present paper deals with the anglicisms lockdown and shutdown, and their collocates in Slovak and in Hungarian. By performing a quantitative and qualitative analysis of web corpora, we examine the absolute and relative frequency of these nouns from a diachronic perspective. The occurrence of the analysed nouns and collocations in which they act as base words is demonstrated by authentic examples. On the basis of the obtained data, we conclude that the impact of the COVID-19-pandemic can be observed on the lexical level as the studied anglicisms have become established in both languages. Their frequency in Slovak is higher than in Hungarian. The Hungarian language seems to prefer domestic lexemes to their foreign equivalents.
\end{abstract}

Key words: lockdown; shutdown; anglicisms; collocations; corpus analysis

Kl'účové slová: lockdown; shutdown; anglicizmy; kolokácie; korpusová analýza

Subject-Affiliation in New CEEOL: Language and Literatura - Theoretical Linguistics - Lexis

DOI: $10.36007 /$ eruedu.2021.4.31-43

\section{1 Úvod}

Skúmanie vzájomného vztahu jazyka a spoločnosti je jedným z predmetov sociolingvistiky. Aktuálne dianie v spoločnosti sa signifikantným spôsobom podiel'a na formovaní lexiky každého jazyka dochádza pritom viacerými intralingválnymi, ale aj interlingválnymi procesmi, pri ktorých sa využivajú exogénne lexikálne prvky. Dobrík $(2020,311)$ zdôrazňuje, že pri týchto procesoch často vznikajú nové obsahové komponenty významu, ktoré rozširujú sémantiku vybraných lexém. V prípade, že v jazyku daná lexéma ešte neexistuje, ide o neologizmy. V súčasnej globalizovanej spoločnosti je pomerne časté preberanie slov z angličtiny. Z onomaziologického hl'adiska anglická lexika preniká do viacerých domén, ako napr. do oblasti vedy (call for papers), techniky (kliknút), športu (fit), módy (outfit), politiky (lobby) a pod. Prevzaté slová (výpožičky) v preberajúcom jazyku prechádzajú procesom adaptácie na foneticko-fonologickej, morfologickej, slovotvornej či ortografickej úrovni. Z fónického a grafického hl'adiska si novšie prevzaté slová zachovávajú pôvodnú výslovnost' a pravopis (porov. Katreniaková 2002, 6). Morfologická adap- 
tácia znamená prispôsobenie prevzatého slova gramatickým kategóriám slovných druhov v ciel'ovom, resp. preberajúcom jazyku. Ako príklad Katreniaková (2002, 10) uvádza prevzaté substantíva, ktoré sa v procese adaptácie zaradia do deklinačného systému slovenčiny (kemping - kempingu). Prevzaté slová následne vytvárajú v ciel'ovom jazyku slovotvorné hniezda: surf - surfový - surfovat' - surfovanie - surfista (porov. Katreniaková 2002, 19).

V súvislosti s epidemickou situáciou v rokoch 2020 a 2021 sa do popredia dostávali jednak domáce ustálené slovné spojenia, ako aj odborné termíny (reprodukčné číslo, antigénový test, spike proteín a i.), no relatívne rýchlo začali do jazyka prenikat' aj niektoré anglicizmy, ako napr. lockdown a shutdown, pričom nie všetky sa dostatočne etablovali (napr. blackout). V slovenskom kontexte vzniklo niekol'ko prác venovaných práve vplyvu pandémie na slovnú zásobu, ale aj koronalexike ako politickému nástroju (porov. Dobrík 2020; Kášová 2020; Kášová Tomášiková - Hrdinová 2020; Škvareninová 2020; Vargová 2021).

S ciel'om približit' význam termínov súvisiacich s pandémiou vypracoval Rusnák tzv. Malý slovník jazyka COVID-19 (porov. Rusnák 2020). Spomínaný slovník a Slovníkový portál Jazykovedného ústavu Ĺudovíta Štúra SAV však neponúkajú definície substantív lockdown a shutdown. Jazykovedný ústav L'. Štúra SAV zozbieral na základe analýz Slovenského národného korpusu terminologickú zbierku výrazov spojených s koronavírusom pod názvom Epidemiológia a imunológia (porov. Slovenská terminologická databáza 2021). Pri tvorbe zbierky boli smerodajné nielen encyklopédie medicíny a lekárske slovníky, ale aj terminologické databázy a zahraničné glosáre. Zbierka neuvádza anglicizmy lockdown a shutdown, čo možno pripisovat' tomu, že nesúvisia priamo s medicínskou terminológiou. Z uvedených dôvodov sa $v$ predloženom príspevku venujeme týmto anglicizmom z pohl'adu ich integrácie do lexikálneho systému slovenčiny a mad'arčiny, pričom hlavným predmetom analýzy je ich kolokabilita.

\section{Metódy}

Pre výskumné účely sme vytvorili dva špecializované webové korpusy použitím korpusového manažéra Sketch Engine ${ }^{1}$ (Kilgariff et al., 2014). Ako klúčové slová sme pri kompilovaní slovenského korpusu zadali slová: shutdown, lockdown, korona, koronavírus, vírus, covid, covid-19, pandémia. Celková vel'kost' skúmaného slovenského korpusu je $\mathrm{N}_{\mathrm{S}}=1.240 .726$ tokenov. Pre vytvorenie mad'arského korpusu sme použili nasledovné kl'účové slová: shutdown, lockdown, koronavírus, vírus, covid, covid-19, járvány. Vel'kost' mad'arského korpusu predstavuje $\mathrm{N}_{\mathrm{M}}=$ 962.598 tokenov.

$\mathrm{V}$ prvom kroku analýzy sme $\mathrm{v}$ oboch korpusoch skúmali absolútnu a relatívnu frekvenciu substantív lockdown a shutdown v slovenčine a v mad'arčine. Z jednotlivých konkordancií boli následne odfiltrované falošné výskyty. Výskyty získané v našich korpusoch sme konfrontovali s väčšími webovými korpusmi Aranea ${ }^{2}$ (porov.

1 http://www.sketchengine.eu

2 http://ucts.uniba.sk 
Benko et al. 2014a; 2014b) s ciel'om porovnat' ich frekvenciu v čase.

Hlavným ciel'om analýzy bolo preskúmat' ustálené slovné spojenia predmetných substantív v oboch jazykoch. Kolokáty anglicizmov lockdown a shutdown sme excerpovali použitím funkcie Collocations, pričom sme zo štatistického hl'adiska zohl'adnili mieru asociatívnosti logDice (porov. Rychlý 2007; Benko et al. 2019, 44). Ako hraničnú hodnotu koeficientu sme zvolili logDice $\geq 8$. Výsledky sú prezentované $v$ tabul'kovej forme a signifikantné slovné spojenia dokladujeme autentickými príkladmi zo skúmaných korpusov.

S ciel'om porovnat' frekvencie skúmaných anglicizmov v kontexte času sme vybrali webový korpus slovenského jazyka Araneum Slovacum V Maximum (porov. Benko et al. 2014a; 2014b). Jeho vel'kost' zodpovedá hodnote $N=4.042 .371 .409$ tokenov. Tento korpus reflektuje použivanie skúmaných lexém v rozpätí od 2013 do 2019.

Absolútna frekvencia anglicizmu lockdown dosahuje po odstránení falošných výskytov hodnotu $F(S)_{\text {lockdown }}=23 \mathrm{~s}$ relatívnou frekvenciou $\mathrm{f}(\mathrm{S})_{\text {lockdown }}=0,001$. Pri podstatnom mene shutdown sme z celkových 726 výsledkov odstránili vlastné mená a iné falošné výskyty, ako napr. názvy príkazov v informačno-komunikačných technológiách, názvy piesní či albumov a pod. Takto získaná frekvencia dosahuje hodnotu $F(S)_{\text {shutdown }}=377$, pričom relatívna frekvencia daného anglicizmu zodpovedá hodnote $\mathrm{f}(\mathrm{S})_{\text {shutdown }}=0,09$. Pred pandémiou COVID-19 sa skúmané anglicizmy používali v slovenčine spravidla v kontexte tzv. shutdownu americkej vlády či informačno-komunikačných technológií, ako demonštrujú nasledovné príklady.

(1) Vd'aka novým funkciám, ako je Pick and Roll Control, Defensive Lockdown Control, Signature Playcalling a Quickstrike Ankle-Breakers, bude hranie NBA LIVE zábavné od samého začiatku. ${ }^{3}$

(2) Korektné vypnutie virtuálnych systémov zabezpečuje hostitel'ský server prostredníctvom samotnej služby Hyper-V, pričom na tomto beží služba APC Network Monitor, ktorá spúšta shutdown fyzického servra. ${ }^{4}$

Korpus mad'arského jazyka Araneum Hungaricum Maius z roku 2014 obsahuje 1.200.001.609 tokenov. Na základe zistených údajov konštatujeme, že absolútna frekvencia anglicizmu lockdown je $\mathrm{F}(\mathrm{M})_{\text {lockdown }}=133$ a relatívna frekvencia zodpovedá hodnote $\mathrm{f}(\mathrm{M})_{\text {lockdown }}=0,11$. Po odfiltrovaní falošných výskytov je frekvencia daného anglicizmu nulová. Analýza ukázala, že skúmaný anglicizmus sa pred vypuknutím pandémie použival najmä v kontexte počítačových aplikácií (3). Absolútna hodnota substantíva shutdown pred filtrovaním odpovedí je $F(M)_{\text {shutdown }}=151$, pričom relatívna frekvencia je $\mathrm{f}(\mathrm{M})_{\text {shutdown }}=0,13$. Filtrovaním klesla hodnota absolútnej frekvencie na $\mathrm{F}(\mathrm{M})_{\text {shutdown }}=57$ a hodnota relatívnej frekvencie na $\mathrm{f}(\mathrm{M})_{\text {shutdown }}=$ 0,04 . Podobne ako v slovenskom jazyku, aj tu išlo zväčša o významovú spojitost' s modernými technológiami, no analyzovaný anglicizmus sa použival aj v kontexte tzv. amerického shutdownu a v niektorých prípadoch sa vztahoval aj na vynútené prerušenie činnosti počítača.

$3 \mathrm{http}: / /$ www.autoomega.sk/

$4 \mathrm{http}: / /$ www.movements.sk/sk/sluzby/pripadove/30 
(3) Ma déltöl így csökken a Skydigital Lockdown, Synology és Mede8er termékek ára, utóbbiból ma érkezik meg a régen várt szállitmány, a Synology-ból pedig holnap indul el hozzánk, és a jövő hét közepén a terveknek megfelelően itt is kell lennie. ${ }^{5}$

(4) A képviselőház - készülve az Amerikában shutdownnak nevezett eshetőségre - vasárnap elfogadott egy törvényt, amely október 1-je után is biztosítaná a katonák fizetésének folyósítását. ${ }^{6}$

\section{Interpretácia výsledkov}

\section{Ustálené slovné spojenia so substantívami lockdown a shutdown v slovenči- ne}

\subsection{Lockdown}

Absolútna frekvencia anglicizmu lockdown v skúmanom slovenskom korpuse je $\mathrm{F}(\mathrm{S})_{\text {lockdown }}=587$, pričom relatívna frekvencia zodpovedá hodnote $\mathrm{f}(\mathrm{S})_{\text {lockdown }}=$ 473,11. Epidemická situácia v rokoch 2020 a 2021 mala za následok, že tento anglicizmus výrazne prenikol hlavne do jazyka médii, ktorého špecifiká svojím charakterom reflektuje náš webový korpus. Možno teda predpokladat', že jeho pomerne časté použivanie viedlo $\mathrm{k}$ etablovaniu istých ustálených slovných spojení v preberajúcom jazyku. V nasledujúcej časti preskúmame adjektívne a verbálne kolokáty spájajúce sa so substantívnou bázou lockdown.

Prídavné mená ako kolokáty anglicizmu lockdown udávame v tabul'ke č. 1 . Lexémy sú zoradené podl'a klesajúcej frekvencie, pričom splńajú podmienku logDice $\geq 8$.

Tabul'ka č. 1 Adjektívne kolokáty substantíva lockdown

\begin{tabular}{|l|l|l|l|}
\hline Lema & Frekvencia & LogDice & Slovné spojenie \\
\hline tvrdý & 40 & 10,72 & tvrdý lockdown \\
\hline prísny & 36 & 10,39 & prísny lockdown \\
\hline čiastočný & 24 & 9,98 & čiastočný lockdown \\
\hline celoplošný & 18 & 9,45 & celoplošný lockdown \\
\hline celoštátny & 9 & 8,67 & celoštátny lockdown \\
\hline trojdňový & 8 & 8,55 & trojdňový lockdown \\
\hline úplný & 9 & 8,47 & úplný lockdown \\
\hline plošný & 9 & 8,43 & plošný lockdown \\
\hline
\end{tabular}

Na základe zistených údajov konštatujeme, že tvrdý, prísny a čiastočný sú najčastejšie vyskytujúce sa adjektívne kolokáty anglicizmu lockdown. Kolokáty poukazujú na intenzitu a mieru zavedenia lockdownu s ciel'om spomalit šírenie ko-

5 http://neon-multimedia.hu/?oldal=hirek

6 http://www.arany9999.eu/posts/show/2442/orak_kerdese_az_allamcsod 
ronavírusu. Tvrdý a prísny lockdown označujú výrazné obmedzenie vol'ného pohybu l'udí za striktných podmienok, kým čiastočný lockdown popisuje obmedzenia v menšom rozsahu. Možno teda konštatovat', že uvedené kolokácie sa z pohl'adu sémantiky týkajú prevažne intenzity zavedených opatrení, ale aj ich geografického ohraničenia (plošný, celoplošný, celoštátny).

Nasledujúce príklady $(5,6$ a 7$)$ demonštrujú použitie najčastejších adjektív v súvislosti s prezentovaním opatrení verejnosti národnými inštitúciami či autoritami:

(5) Zástupcovia federálnej vlády i spolkových krajín súhlasili s návrhom zaviest' tvrdý lockdown v prípade, že sedemdňová miera incidencie narastie na viac než 100 nových prípadov na 100.000 obyvatel'ov. $^{7}$

(6) Zástupca primátorky najprv navrhoval krátky, prísny lockdown s následným opätovným otvorením reštaurácií alebo kultúrnych centier. ${ }^{8}$

(7) Podl'a Merkelovej novembrové opatrenia, ked' bol zavedený len čiastočný lockdown, nepreukázali výrazný pokles počtu nakazených. ${ }^{9}$

Tabul'ka č. 2 sumarizuje verbálne kolokáty substantíva lockdown, ktorých hodnota logDice zodpovedá stanovenému kritériu $\geq 8$.

Tabul'ka č. 2 Verbálne kolokáty substantíva lockdown

\begin{tabular}{|l|l|l|l|}
\hline Lema & Frekvencia & LogDice & Slovné spojenie \\
\hline platit' & 19 & 8,88 & lockdown platí \\
\hline zaviest' & 15 & 9,20 & zaviest' lockdown \\
\hline hrozit' $^{\prime}$ & 13 & 9,02 & lockdown hrozí \\
\hline predlžovat' & 10 & 8,84 & predlžovat' lockdown \\
\hline predížit' & 10 & 8,69 & predízit' lockdown \\
\hline zavádzat' & 9 & 8,63 & zavádzat' lockdown \\
\hline trvat' $^{\prime}$ & 8 & 8,14 & lockdown trvá \\
\hline pripomínat' & 6 & 8,03 & niečo pripomína lockdown \\
\hline
\end{tabular}

Vyššie znázornený prehl'ad verbálnych kolokátov reflektuje najčastejšie použivané verbo-nominálne spojenia. Pre všetky kolokáty platí, že sa vztahujú na samotné trvanie lockdownu a nie na ukončenie výnimočnej situácie. Pri slovesách platit', zaviest' a predízit' pozorujeme najvyššiu frekvenciu (porov. príklady 8, 9 a 10).

(8) Ked'že počty infikovaných sa nepodarilo dostat' pod kontrolu, od 16. decembra platí súčasný lockdown , ktorý sa mal pôvodne skončit' 10. januára. ${ }^{10}$

\footnotetext{
7 https://mediweb.hnonline.sk/spravy/2320038-nemecko-sa-pripravuje-na-tvrdy-lockdown

8 https://www.topky.sk/cl/11/2070579/KORONAVIRUS-Vikendovy-lockdown-v-meste-by-bol-neludsky-tvrdi-primatorka-Pariza

9 https://spravy.pravda.sk/domace/clanok/571766-online-ockovanie-proti-koronavirusu-bude-trvat-mesiace/

10 https://domov.sme.sk/c/22566444/koronavirus-slovensko-pripady-vakcina-lockdown-co-
} 
(9) Vedenie anglického mesta Liverpool žiada britskú vládu, aby opätovne zaviedla lockdown na celom území krajiny s ciel'om zastavit' šírenie nového variantu koronavírusu. ${ }^{11}$

(10) Vláda prijala nové opatrenia, ak nezaberú, hrozí tvrdý lockdown. ${ }^{12}$

Slovné spojenie lockdown (niekomu) hrozí reflektuje percepciu opatrení proti šireniu koronavírusu v mediálnom diskurze, ako aj isté anticipovanie zhoršenej situácie.

\subsection{Shutdown}

Na základe analýzy výskytu substantíva shutdown konštatujeme absolútnu frekvenciu $F(S)_{\text {shutdown }}=260$ a relatívnu frekvenciu s hodnotou $\mathrm{f}(\mathrm{S})_{\text {shutdown }}=209,55$ na milión tokenov.

Tabul'ka č. 3 Adjektívne kolokáty substantíva shutdown

\begin{tabular}{|l|l|l|l|}
\hline Lema & Frekvencia & LogDice & Slovné spojenie \\
\hline tzv. & 31 & 10,93 & tzv. shutdown \\
\hline čiastočný & 29 & 11,26 & čiastočný shutdown \\
\hline americký & 21 & 8,56 & americký shutdown \\
\hline takzvaný & 20 & 10,58 & takzvaný shutdown \\
\hline dlhý & 11 & 9,47 & dlhý shutdown \\
\hline federálny & 9 & 9,17 & federálny shutdown \\
\hline mierny & 3 & 8,05 & mierny shutdown \\
\hline zmienený & 3 & 8,32 & zmienený shutdown \\
\hline
\end{tabular}

Vyššie uvedené adjektívne kolokáty sa vztahujú prevažne na situáciu v Spojených štátoch amerických a nie na samotnú pandémiu:

(11) Po 69 hodinách sa tak skončil takzvaný shutdown , počas ktorého bola ochromená činnost' mnohých vládnych inštitúcií v USA. ${ }^{13}$

11 https://domov.sme.sk/c/22565458/koronavirus-slovensko-pripady-vakcina-lockdown-covid-03-01.html

12 https://www.24hod.sk/koronavirus-vlada-prijala-nove-opatrenia-ak-nezaberu-hrozi-tvrdy-lockdown-platit-by-mali-od-3-marca-cl750809.html

13 https://www.tvnoviny.sk/zahranicne/1903646_trump-podpisal-zakon-o-obnoveni-financovania-federalnych-uradov 
V tabul'ke č. 4 tabul'ke sumarizujeme najfrekventovanejšie verbálne kolokáty, ktoré sa v skúmanom korpuse vyskytujú s anglicizmom shutdown:

Tabul'ka č. 4 Verbálne kolokáty substantíva shutdown

\begin{tabular}{|l|l|l|l|}
\hline Lema & Frekvencia & LogDice & Slovné spojenie \\
\hline skončit' & 15 & 9,05 & shutdown skončí \\
\hline spustit' & 5 & 8,64 & spustit' shutdown \\
\hline hrozit' $^{\prime}$ & 5 & 8,59 & shutdown hrozí \\
\hline podpisat' & 5 & 8,70 & podpisat' shutdown \\
\hline pokračovat' & 5 & 8,05 & shutdown pokračuje \\
\hline končit' & 4 & 8,43 & shutdown sa končí \\
\hline pohrozit' & 4 & 8,72 & pohrozit' shutdownom \\
\hline financovat' & 3 & 8,11 & financovat' shutdown \\
\hline
\end{tabular}

V pripade verbálnych kolokátov opätovne pozorujeme význam súvisiaci s čiastočným uzavretím vlády v USA:

(12) V Amerike skončil shutdown. Trump podpísal zákon o obnovení financovania federálnych úradov. ${ }^{14}$

Po preskúmaní najčastejších kolokácií zo sémantického hl'adiska sme neidentifikovali významový súvis s epidemickou situáciou. Z výsledkov vyplývajúcich zo skúmanej vzorky možno konštatovat', že v slovenčine sa anglicizmus shutdown v porovnaní s anglicizmom lockdown nepresadil, no zároveň by bolo vhodné rozšírit' skúmaný materiál. Odlišná situácia je napríklad v nemčine, kde sa tieto podstatné mená použivajú v kontexte pandémie ako synonymá. ${ }^{15}$

Okrem vyššie uvedeného významu nachádzame použivanie anglicizmu shutdown v kontexte informačných technológií, a to vo význame vypnutia zariadenia:

(13) Minule som hladal na google play aplikaciu na shutdown zariadenia, lebo slavne android zariadenie (nie mobil), taku volbu nema. ${ }^{16}$

Záverom možno ešte spomenút niekol'ko domácich a exogénnych lexém s podobnou sémantikou. $V$ roku 2020 sa $v$ istom momente $v$ médiách začal objavovat' pojem blackout, ktorého absolútna frekvencia v skúmanom korpuse je $F=43$, pričom jeho relatívna frekvencia zodpovedá hodnote $f=34,66$. K významným slovným spojeniam patrí napríklad úplný blackout so štatistickými hodnotami $\mathrm{F}=3$ a logDice $=9,38$. Jeho použitie, ako extrémnej formy lockdownu, demonštruje nasledujúci príklad:

\footnotetext{
14 https://hnonline.sk/svet/1680108-v-amerike-skoncil-shutdown-trump-podpisal-zakon-o-obnoveni-financovania-federalnych-uradov 15 https://www.dwds.de/wb/Shutdown (citované 10.07.2021) 16 https://zive.aktuality.sk/diskusia/113650/v-google-play-odhalili-104-skodlivych-aplikacii/
} 
(14) Matovič už otvorene volá po úplnom blackoute krajiny. ${ }^{17}$

Na ilustráciu sémanticky podobných pojmov možno v slovenčine uviest' slovné spojenie zákaz vychádzania s celkovou absolútnou frekvenciou 237 a koeficientom logDice $=13,72$, prípadne zákaz zhromažd'ovania sa s absolútnou frekvenciou 13 a logDice $=10,25$. V tomto prípade ide tiež o signifikantné slovné spojenia, ktoré vstupujú do vyšších celkov, ako napr.: nočný zákaz vychádzania $(F=11$; logDice $=11,57)$, prísny zákaz vychádzania $(F=17$; logDice $=11,05)$ či zákaz vychádzania platí $(\mathrm{F}=33$; logDice $=12,31)$.

\section{Ustálené slovné spojenia so substantívami lockdown a shut- down v mad'arčine}

\subsection{Lockdown}

Analýza korpusu mad'arského jazyka preukázala nasledovné hodnoty: absolútna frekvencia zodpovedá $F(M)_{\text {lockdown }}=273$ a relatívna frekvencia $f(M)_{\text {lockdown }}=283,61$. $\checkmark$ tabul'ke č. 5 sú s klesajúcou frekvenciou znázornené tie kolokáty, ktoré vyhovujú podmienke logDice $\geq 8$.

Tabul'ka č. 5 Adjektívne kolokáty substantíva lockdown

\begin{tabular}{|l|l|l|l|}
\hline Lema & Frekvencia & LogDice & Slovné spojenie \\
\hline szigorú [prísny] & 14 & 9,47 & szigorú lockdown \\
\hline teljes [úplný] & 13 & 8,47 & teljes lockdown \\
\hline harmadik [tretí] & 8 & 8,04 & harmadik lockdown \\
\hline $\begin{array}{l}\text { közepesen szigorú } \\
\text { [stredne prísny] }\end{array}$ & 4 & 8,16 & közepesen szigorú lockdown \\
\hline
\end{tabular}

Zistené adjektívne kolokáty bližšie popisujú mieru, intenzitu a poradie obmedzenia vol'ného pohybu obyvatel'stva v pandemickom období. $Z$ hore uvedených údajov je zrejmé, že prídavné mená szigorú, teljes a harmadik, t. j. prísny, úplný a tretí sa najčastejšie viažu so skúmanou substantívnou bázou. V tabul'ke figuruje aj spojenie közepesen szigorú lockdown [stredne prísny lockdown], ktoré vyjadruje už slabšiu intenzitu prijatých opatrení.

(15) Tizenöt nap szigorú lockdown után sem sikerült megtörni a járványgörbét, a helyzet javulása nem olyan ütemü, mint más országokban, ami akár a brit mutáció következménye is lehet - jelentette ki Marek Krajčí (OL'ANO) egészségügyi miniszter pénteki sajtótájékoztatóján. ${ }^{18}$

\footnotetext{
17 https://slovensko.hnonline.sk/2123547-matovic-uz-otvorene-vola-po-uplnom-blackoute-krajiny-vysvetlil-co-by-to-pre-slovensko-znamenalo

18 https://korkep.sk/cikkek/uncategorized/2021/01/15/krajci-15-nap-szigoru-lockdown-utan-sem-sikerult-megtornunk-a-jarvanygorbet/
} 
(16) És amikor augusztusban egy 27 éves nő személyében az első pozitív esetet rögzítették a karanténon kívül, háromhetes teljes lockdown lépett életbe. ${ }^{19}$

(17) Boris Johnson mindenáron el akarja érni, hogy a harmadik "lockdown" egyben az utolsó legyen, ennek érdekében a nyitás óvatos és fokozatos lesz. ${ }^{20}$

(18) Térségünket tekintve a magyar lockdown közepesen szigorú, a halálozási rátánk viszont magas. ${ }^{21}$

V skúmanom materiáli sme našli iba jeden verbálny kolokát, ktorý spíña stanovené kritérium logDice. Ide o sloveso bevezetés (lockdown bevezetése), t. j. zavedenie lockdownu a popisuje nadobudnutie platnosti obmedzení pri istých činnostiach obyvatel'stva. Absolútna frekvencia daného slovného spojenia je $F=4 \mathrm{~s}$ hodnotou logDice $=8,04$.

(19) Kijev polgármestere országos lockdown bevezetését szorgalmazza. ${ }^{22}$

\subsection{Shutdown}

V mad'arskom korpuse zist'ujeme pri anglicizme shutdown nízke hodnoty výskytu. Jeho absolútna frekvencia zodpovedá $\mathrm{F}(\mathrm{M})_{\text {shutdown }}=71$ a hodnota relatívnej frekvencie je $\mathrm{f}(\mathrm{M})_{\text {shutdown }}=73,76$. Na základe týchto zistení môžeme konštatovat', že substantívum shutdown sa dostalo do lexiky daného jazyka len v obmedzenej miere. Z tohto dôvodu sú kolokáty spájajúce sa s touto substantívnou bázou zastúpené iba $\mathrm{v}$ malom rozsahu.

Na tomto mieste môžeme uviest' dva adjektívne kolokáty, ktoré vyhovujú stanovenej podmienke logDice $\geq 8$. Ide o úgynevezett shutdown [takzvaný shutdown] a o slovné spojenie gazdasági shutdown [hospodársky shutdown]. Slovné spojenie úgynevezett shutdown nachádzame v skúmanom korpuse v 15 kontextoch, pričom hodnota logDice je = 11,07. Gazdasági shutdown figuruje v korpuse štyrikrát, a tým dosahuje hodnotu logDice $=8,21$.

(20) Az úgynevezett Shutdown ideje alatt fel kell készülni a következő szakaszra, a célzottabb intézkedések időszakára, amelyben minden eddiginél szélesebb körben kell majd koronavírus-tesztet végezni a fertőzésgyanús esetekben és az ország területére belépőknél, és folyamatosan ellenőrzés alatt újra be kell indítani a gazdaság és a társadalom egyes kiválasztott területeinek

19 https://www.msn.com/hu-hu/hirek/other/egy-koldusszeg\%C3\%A9ny-orsz\%C3\%A1g-legy\%C5\%91zte-a-koronav\%C3\%ADrust/ar-BB1dFS3R

20 https://nepszava.hu/3110699_megkezdodik-a-visszaszamlalas

21 https://privatbankar.hu/cikkek/makro/megugrott-a-halalozas-europaban-magyarorszag-is-sulyosan-erintett.html

22 https://karpathir.com/2021/04/09/kijev-polgarmestere-orszagos-lockdown-bevezeteset-szorgalmazza/ 
müködését - javasolják a Leopoldina szakértői. ${ }^{23}$

(21) Mindenki sejtette, hiszen egy globális gazdasági shutdown történt. ${ }^{24}$

Analýza ukázala, že anglicizmy lockdown a shutdown sa v mad'arskom jazyku použivajú iba $v$ malej miere. Namiesto jazykových prvkov prevzatých $z$ angličtiny sa uplatňujú slová domáceho pôvodu, a síce: (le)zárás, [zatvorenie niečoho] a/alebo leállítás [zastavenie niečoho, napr. prevádzky] (porov. DictZone, 2021). Použitie uvedených slovných spojeni v kontexte demonštrujú nasledovné príklady.

(21) A távközlési szolgáltatókkal szembeni elégedetlenség minden bizonnyal szintén a lezárásokkal függ össze - mondta a közlemény szerint Horváth Gergely, a Comnica üzletfejlesztési igazgatója. ${ }^{25}$

(22) Az internetes filmforgalmazás az iparágban egyébként elkönyvelt veszteségek ellensúlyozására is alkalmas volt, hiszen a mozik bezárása és a nagyobb produkciók forgatásának leállítása miatt új alapokra kellett helyezni a bevételi lehetőségeket. ${ }^{26}$

\section{Diskusia a záver}

Predkladaný príspevok sa zameriava na anglicizmy lockdown a shutdown a na ich ustálené spojenia v slovenskom a v mad'arskom jazyku. Analýzy absolútnej a relatívnej frekvencie $v$ rámci vytvorených špecializovaných korpusov a dostupných webových korpusov Araneum poukazujú na etablovanie predmetných substantív do jazyka vplyvom pandémie COVID-19.

V špecializovanom slovenskom korpuse bola absolútna hodnota anglicizmu lockdown $F(S)_{\text {lockdown }}=587$ a jeho relatívna frekvencia zodpovedala hodnote $f(S)$ lockdown $=473,11$. Pri porovnani s hodnotami z Araneum Slovacum V Maximum korpusu je zrejmé, že ide o niekol'konásobný nárast výskytu anglicizmu lockdown v slovenčine. $V$ porovnávacom korpuse totiž dosahoval diskutovaný anglicizmus absolútnu frekvenciu $F(S)_{\text {lockdown }}=23$ a relatívnu frekvenciu $f(S)_{\text {lockdown }}=0,001$. Zistené kolokáty podčiarkujú výskyt skúmaného substantíva $v$ kontexte pandémie. $S$ najväčšou hodnotou logDice sa javili nasledujúce adjektívne kolokáty: tvrdý lockdown $(10,72)$, prísny lockdown $(10,39)$ a čiastočný lockdown $(9,98)$. $\mathrm{Na}$ základe výsledkov je možné konštatovat', že sa dané kolokáty vztahovali na mieru a intenzitu lockdownu v spoločnosti. Analýza zároveň odhalila najčastejšie sa vyskytujúce verbálne kolokáty, a síce: zaviest' lockdown $(9,20)$, lockdown hrozí $(9,02)$ a lockdown platí $(8,88)$. Zo sémantického hl'adiska popisujú trvanie konkrétnych obmedzení.

Na rozdiel od substantíva lockdown, bol výskyt druhého skúmaného angliciz-

23 https://www.origo.hu/nagyvilag/20200322-nemetorszagban-lassul-a-koronavirus-terjedese.html 24 https://pestisracok.hu/ez-nem-rendkivuli-vakacio/

25 https://forbes.hu/uzlet/felmeres-comnica-webshop-hazhozszallitas-covid-ugyfel/

26 https://www.pwc.com/hu/hu/kiadvanyok/assets/pdf/Kenyszerpiheno_helyett_tulorak_avagy_ kik_a_COVID-19_nyertesei.pdf 
mu relatívne vysoký aj pred vypuknutím pandémie. Absolútna frekvencia anglicizmu shutdown dosiahla hodnotu $F(S)_{\text {shutdown }}=377$ a jeho relatívna frekvencia bola $f(S)$ shutdown $=0,09$. Použivanie daného anglicizmu však bolo zväčša späté s americkou vládou a s kontextom informačno-komunikačných technológii. Absolútna frekvencia shutdownu v špecializovanom korpuse zodpovedala hodnote $F(S)_{\text {shutdown }}=260$, pričom jej relatívna frekvencia dosiahla $\mathrm{f}(\mathrm{S})_{\text {shutdown }}=209,55$. Tu išlo tak o kontext amerického shutdownu, ako aj o tematizovanie pandémie COVID-19. Analýza korpusu odhalila niekol'ko adjektívnych kolokátov. Najväčšiu hodnotu logDice vykazovali nasledujúce slovné spojenia: čiastočný shutdown $(11,26)$, tzv. shutdown $(10,93)$ a takzvaný shutdown $(10,58)$. S najvyššou frekvenciou sa vyskytovali nasledujúce verbálne kolokáty: shutdown skonči $(9,05)$, podpísat' shutdown $(8,70)$, spustit' shutdown $(8,64)$ a shutdown trvá $(10,79)$.

Analýza anglicizmu lockdown v mad'arskom korpuse Araneum ukázala nízku mieru použivania. Po odfiltrovaní falošných výskytov konštatujeme nulovú frekvenciu výskytu. $V$ špecializovanom korpuse zodpovedala absolútna frekvencia hodnote $\mathrm{F}(\mathrm{M})_{\text {lockdown }}=273$ a relatívna frekvencia dosahovala hodnotu $\mathrm{f}(\mathrm{M})_{\text {lockdown }}=283,61 \mathrm{~V}$ mad'arčine zároveň sledujeme menšie spektrum adjektívnych kolokátov substantíva lockdown než v slovenskom jazyku. S najväčšou hodnotou logDice sa preukázali: szigorú lockdown [prísny lockdown] $(9,47)$, teljes lockdown [úplný lockdown] $(8,47)$ a közepesen szigorú lockdown [stredne prísny lockdown] $(8,04)$. Uvedené slovné spojenia, podobne ako v slovenčine, popisujú mieru a intenzitu zavedených opatrení. Zo slovesných kolokátov je možné uviest' iba jeden, a síce: lockdown bevezetése [zavedenie lockdownu]. Ďalšie slovesné spojenia totiž nezodpovedajú stanovenej podmienke logDice. Na základe získaných údajov konštatujeme, že pandémia COVID-19 a s ňou spojené opatrenia majú vplyv na obohacovanie lexiky, ked'že anglicizmus lockdown sa použivatel'mi jazyka použiva a zároveň vstupuje do slovných spojení.

Absolútna frekvencia anglicizmu shutdown v mad'arčine po odfiltrovaní falošných výskytov zodpovedala $F(M)_{\text {shutdown }}=57$ a relatívna frekvencia mala hodnotu $f(M)_{\text {shut- }}$ down $=0,04$. Spravidla išlo o kontext informačno-komunikačných technológii a o americký shutdown. Podobné nízke hodnoty sledujeme aj pri špecializovanom korpuse. Tu dosiahla absolútna frekvencia hodnotu $\mathrm{F}(\mathrm{M})_{\text {shutdown }}=71$ a relatívna frekvencia hodnotu $\mathrm{f}(\mathrm{M})_{\text {shutdown }}=73,76$. Stanovenej podmienke logDice zodpovedali iba dva adjektívne kolokáty: úgynevezett shutdown [takzvaný shutdown] a gazdasági shutdown [hospodársky shutdown]. Verbálne slovné spojenia analýza nepreukázala.

Získané výsledky naznačujú, že anglicizmy lockdown a shutdown sa postupne dostávajú do skúmaných jazykov, no s odlišnou intenzitou použivania. V kontexte slovenského jazyka sa ukazuje, že vplyv pandémie COVID-19 a s ňou prichádzajúce opatrenia majú v skúmaných korpusoch výraznejši dopad na jazyk ako v mad'arčine. Táto skutočnost' má za následok, že aj slovné spojenia s danou bázou vznikajú v slovenskom jazyku vo väčšej miere. Pre vyslovenie komplexných záverov by bolo potrebné skúmat' analyzovaný jav v oboch jazykoch z dlhodobého hl'adiska. 


\section{Literatúra}

Aranea Web Corpora. http://ucts.uniba.sk

Benko, Vladimír (2014a): Aranea. Yet Another Family of (Comparable) Web Corpora. In: Sojka, P., Horák, A., Kopeček, I., Pala, K. (Eds.) 2014. Text, Speech and Dialogue. 17th International Conference, Brno, Czech Republic, September 8-12, 2014. Proceedings. LNCS 8655. Springer International Publishing Switzerland, 2014, s. 257 - 264. (Online).

Benko, Vladimír (2014b): Compatible Sketch Grammars for Comparable Corpora. In: Abel, A., Vettori, C., Ralli, N. (Eds.) 2014. Proceedings of the XVI EURALEX International Congress: The User in Focus, 15-19 July 2014. Bolzano/Bozen: Eurac Research, s. 417 $-430$.

Benko, Vladimír - Butašová, Anna, Púchovská, Zuzana (2019): Webové korpusy Aranea. Učebnica pre učitel'ov cudzích jazykov, prekladatel'ov, tImočníkov, filológov a študentov filologických odborov. Bratislava: Univerzita Komenského v Bratislave.

DictZone online szótárok, online fordítók. 2021. Citované 16.07.2021 https://dictzone. com/magyar-szlovak-szotar

Digitales Wörterbuch der deutschen Sprache. https://www.dwds.de/ Citované 10.07.2021

Dobrik, Zdenko (2020): Konštruovanie významov v koronavírusovom diskurze. In: Slovenská reč, 2020, roč. 85 , č. 3, s. 307 - 323.

Dolník, Juraj (2010): Všeobecná jazykoveda. Bratislava: Veda.

Kášová, Martina (2020): Politická koronalexika. In: Štefančík, R. (Ed.) 2020. Jazyk a politika: na pomedzí lingvistiky a politológie 5. Bratislava: Ekonomická univerzita v Bratislave. Celouniverzitné pracovisko EUBA. Vydavatel'stvo EKONÓM, 2020, s. 152 - 162

Kášová, Martina - Tomášiková, Slavomíra - Hrdinová, Eva Mária (2020): Koronavírus v slovnej zásobe. Prešov: Vydavatel'stvo Prešovskej univerzity 2020.

Katreniaková, Zdena (2002): Anglicizmy v slovenčine z hl'adiska didaktickej komunikácie. Banská Bystrica: Metodické centrum Banská Bystrica.

Kilgarriff, Adam - Baisa, Vít - Bušta, Jan - Jakubíček, Miloš - Kovář, Vojtěch - Michelfeit, Jan - Rychlý, Pavel - Suchomel, Vit (2014): The Sketch Engine: ten years on. In: Lexicography 1 , S. 7 - 36.

Ludányi, Zsófia (2020). Helyesírási kérdések pandémia idején. In: Amega. 2021/4, s. 33-35.

Ministerstvo investícií, regionálneho rozvoja a informatizácie Slovenskej republiky. 2021. Koronavirus a Slovensko. Citované 14.07.2021 https://korona.gov.sk/

Rychlý, Pavel (2008): A Lexicographer-Friendly Association Score. In: P. Sojka - A. Horák (Eds.) 2008. Proceedings of Recent Advances in Slavonic Natural Language Processing, RASLAN 2008. 2. vyd. Brno, RASLAN 2008. Brno: Masarykova Univerzita, s. 6 - 9.

Rusnák, Martin (2020): Malý slovník jazyka COVID-19. Trnavská univerzita v Trnave. Citované 19.04.2021 https://www.truni.sk/news/maly-slovnik-jazyka-covid-19

Sketch Engine. Dostupné online: http://www.sketchengine.eu

Slovenská akadémia vied: Slovníkový portál Jazykovedného ústavu L'. Štúra SAV. Citované 19.04.2021 https://slovnik.juls.savba.sk 
Škvareninová, Ol'ga (2020): Slovenčina v médiách počas pandémie koronavirusu. In: Lančarič, D. (Ed.) 2020. Jazykovedné, literárnovedné a didaktické kolokvium. Roč. L-7. Bratislava: Z-F LINGUA, s. 167 - 183

Jazykovedný ústav Ĺ. Štúra Slovenskej akadémie vied. 2021. Slovenská terminologická databáza. Citované 13.05.2021 https://terminologickyportal.sk/wiki/Hlavn\%C3\%A1_ str\%C3\%A1nka

Vargová, Dominika (2021): Aktuálne zmeny v slovnej zásobe anglického a slovenského jazyka - jazyk pandémie. In: Lingua et vita 19/2021, s. 93 - 105. 